\title{
Taxonomy of the \\ Genus Thiobacillus: the Outcome of Numerical Taxonomy Applied to the Group as a Whole
}

\author{
By M. HUTCHINSON,* K. I. JOHNSTONE AND D. WHITE \\ The Houldsworth School of Applied Science and the \\ Department of Bacteriology, The University, Leeds
}

(Accepted for publication I May 1969)

\begin{abstract}
SUMMARY
Data from previous numerical analyses have been combined to produce an over-all classification of the genus Thiobacillus; 93 strains were examined using 38 tests and 106 character states. The results indicated the possible existence of a new species and demonstrated an unexpectedly close similarity between $T$. neapolitanus and $T$. thio-oxidans.

A number of diagnostic tests have been selected from those used for the numerical analysis. A brief description of the other important features of each species recognized is also given.
\end{abstract}

\section{INTRODUCTION}

The reasons for this investigation of the taxonomy of the thiobacilli and a description of the numerical methods used were given in an earlier paper (Hutchinson, Johnstone \& White, I965). Originally it had been intended to examine all the species using the same series of tests but this was not possible because of the differing physiological requirements of the various species. For this reason Thiobacillus novellus, $T$. thioparus, $T$. neapolitanus and ' $T$. trautweinii' were tested with thiosulphate as the substrate at pH 6.6 (Hutchinson et al. 1965), whereas $T$. thio-oxidans and $T$. ferrooxidans had to be tested in a similar medium at pH 5 (Hutchinson, Johnstone \& White, I966). The anaerobic species $T$. denitrificans and certain other strains were tested both aerobically and anaerobically at $\mathrm{pH} 6.6$ and $7 \cdot 0$, respectively (Hutchinson, Johnstone \& White, 1967). The data from these tests were analysed numerically and the results were highly significant for the groups of species under test. It was apparent, however, that an over-all indication of the interrelationships of the various species could only be obtained from a single numerical analysis which included all the species.

In an attempt to devise a test series which would be suitable for all the species, serious consideration was given to $\mathrm{pH}$ values in the range between 5.0 and $6 \cdot 6$, but no one value was satisfactory. The choice, therefore, was between a test series in which some of the species would not grow because of the initial $\mathrm{pH}$ value, and a numerical analysis in which the various groups of species were tested at, or near, their optimum $\mathrm{pH}$ value. The latter course was regarded as most appropriate although this involved the abandonment of strict Adansonian principles. To achieve further

* Present address: Water Research Association, Medmenham, Marlow, Bucks. 
uniformity, thiosulphate was chosen as the basal substrate for these tests in that this substrate is utilized by all of the strains.

Numerical methods in taxonomy are designed to remove personal bias from the final result and the authors believe that the present study has been made as objectively as possible. In one instance, however, a separation between two species has been maintained despite the evidence from the numerical analysis.

\section{METHODS}

\section{Organisms}

From the 128 strains available 87 were selected for inclusion in the analysis together with six strains not described previously. The latter are listed in Table $\mathrm{I}$. The strains omitted were mainly from groups 3 and 4 and were in most cases duplicates of strains included in the analysis.

The results for all the tests based on thiosulphate were pooled, irrespective of the $\mathrm{pH}$ value at which the tests were made. Where necessary, new limits were drawn up for the quantitative tests and the data re-scored. Details of the tests are given in Table 2. In this final analysis 106 characters were scored for the 93 strains.

Table I. Strains not previously described and their sources of origin

\section{Source}

R. L. Starkey, Rutgers University, New Jersey

From lagoon system treating carbonization liquor

Natural spring of sulphuretted water

Laboratory scale plant treating gas liquor

$$
\text { Species }
$$

$T$. novellus*

$T$. novellus $\dagger$

$T$. neapolitanus

$T$. neapolitanus

$T$. neapolitanus

$T$. neapolitanus
Code no.

$$
\begin{aligned}
& \text { S I } \\
& \text { S } 2 \\
& 6 \text { G } \\
& 7 \mathrm{G} \\
& \text { I R } \\
& \text { I V }
\end{aligned}
$$

* Maintained on thiosulphate agar. † Maintained on nutrient agar.

Analysis of data

The results were scored according to the method of Beers \& Lockhart (I962) and the $S$ values computed according to the method given by Sneath (1957). The order of the rearranged matrices was obtained by inspection.

\section{RESULTS}

From the rearranged matrix of $\mathrm{S}$ values given in Fig. I it is apparent that the groups 0 to 7 which were found corresponded with those reported previously for the individual series of numerical analyses (Hutchinson et al. 1965, 1966, 1967). A new group was found which had been overlooked in the previous analyses and this has been designated group I $a$. This new group does not correspond to any named species and is represented by only two isolates, IOG and IIG, from a lagoon system treating carbonization effluent.

The essential data from the rearranged matrix of $\mathbf{S}$ values are listed in Table 3. This method, which has been used previously, permits the comparison of two adjacent groups with reference to the central strain of one of the groups. Thus, in the comparison of groups 3 and 4, strain P 2 was selected as the central strain, and the S values 
Table 2. Key to tests used in the final analysis of the thiobacilli

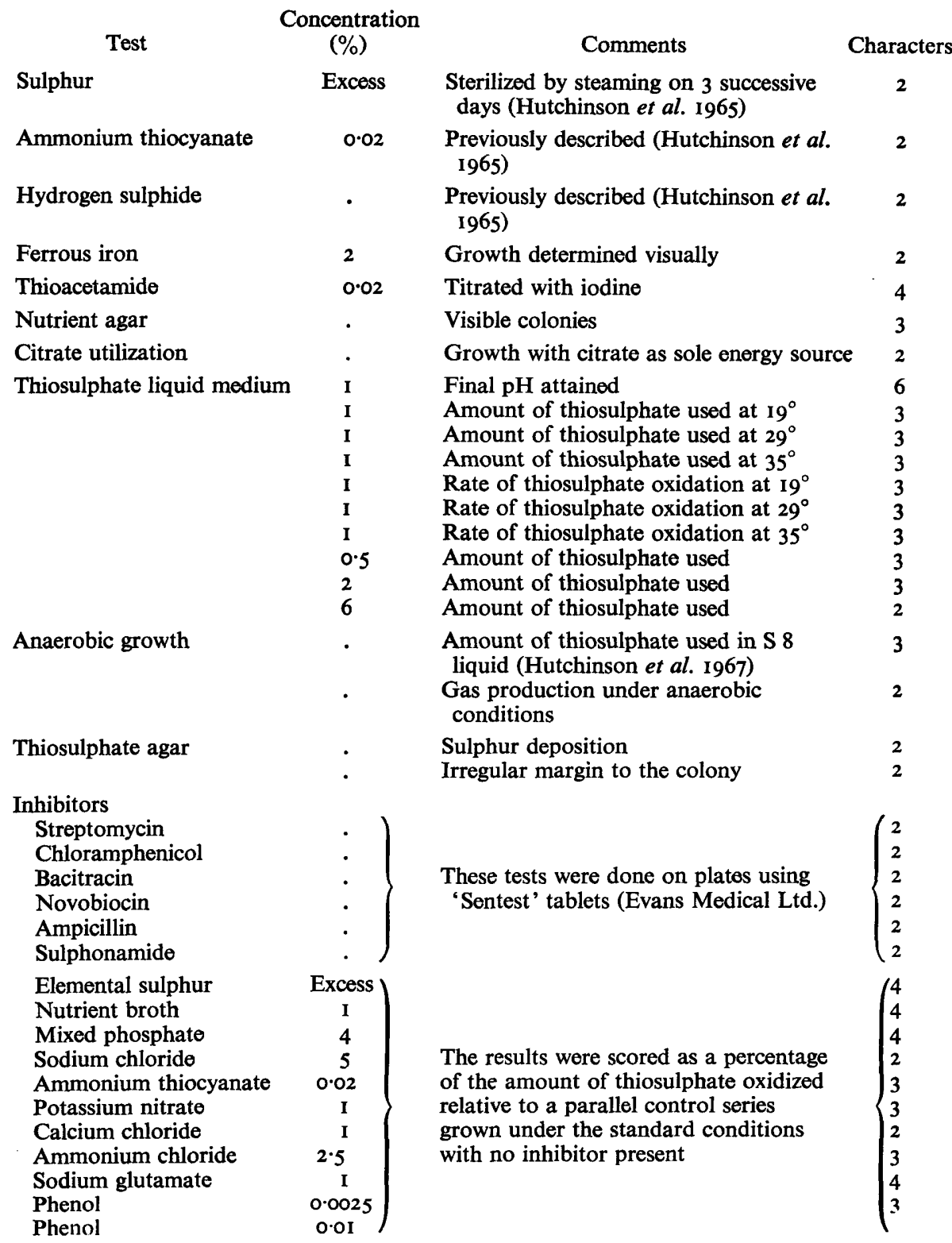

of group 3 to this strain ranged from 74 to 89 , with a mean value of 83 . The highest $S$ values of group 4 to strain P 2 was 57, indicating a gap between the two groups of 17 units. If one assumes a normal distribution of $S$ values about the central organism of each group of plus or minus three standard deviations, the separation of the groups is not as precise as that for the previous individual studies (Hutchinson et al. 1965, 1966, 1967). A certain degree of overlap has arisen largely as a result of the adaptation 
of the scoring system to encompass the wide variety of strains. However, on the basis of the lowest $S$ value of the group with the highest range of $S$ values and the highest $S$ value of the lower group, there is reasonable agreement between all the results of this and the previous analyses.

The overlap between groups 4 and 5 was rather unexpected because, as explained previously, these two groups cannot be tested at the same $\mathrm{pH}$ value. However, once this difference has been removed the two groups are of sufficient similarity to overlap each other on several important points; notably their tolerance of high salt concentrations and growth in $6 \%(\mathrm{w} / \mathrm{v}) \mathrm{Na}_{2} \mathrm{~S}_{2} \mathrm{O}_{3} \cdot 5 \mathrm{H}_{2} \mathrm{O}$.

Table 3. Comparison of $S$ values to the central strains for adjacent groups

\begin{tabular}{|c|c|c|c|c|c|c|c|c|c|}
\hline \multirow[b]{2}{*}{$\mathbf{A}$} & \multirow[b]{2}{*}{ B } & \multicolumn{4}{|c|}{$\begin{array}{l}\mathbf{S} \text { values of group } \mathbf{A} \text { to } \\
\text { central strain of group } \mathbf{A}\end{array}$} & \multicolumn{4}{|c|}{$\begin{array}{l}S \text { values of group B to } \\
\text { central strain of group } A\end{array}$} \\
\hline & & I & 2 & 3 & 4 & 1 & 2 & 3 & 4 \\
\hline $\begin{array}{l}\text { Group o } \\
\text { ( } \mathrm{A} \text { is central strain) }\end{array}$ & Group I $a$ & 89 & 78 & $6 \cdot I$ & 68 & 55 & 52 & $*$ & 49 \\
\hline $\begin{array}{l}\text { Group I } \\
\text { (a I is central strain) }\end{array}$ & Group I $a$ & 97 & 87 & $7 \cdot 6$ & 78 & 55 & 54 & * & 52 \\
\hline $\begin{array}{l}\text { Group o } \\
\text { ( } \mathrm{A} \text { is central strain) }\end{array}$ & Group I & 89 & 78 & $6 \cdot I$ & 68 & 69 & 6I & 5.4 & 52 \\
\hline $\begin{array}{l}\text { Group I } \\
\text { (a I is central strain) }\end{array}$ & Group 2 & 97 & 87 & $7 \cdot 6$ & 78 & 64 & 60 & $2 \cdot 8$ & 58 \\
\hline $\begin{array}{l}\text { Group } 2 \\
\text { (8G is central strain) }\end{array}$ & Group 3 & 94 & 93 & $\mathbf{I} \cdot \mathbf{O}$ & 92 & 73 & 58 & 6.8 & 47 \\
\hline $\begin{array}{l}\text { Group } 3 \\
\text { (p2 is central strain) }\end{array}$ & Group 4 & 89 & 83 & $5 \cdot 0$ & 74 & 57 & 50 & $3 \cdot 0$ & 43 \\
\hline $\begin{array}{l}\text { Group } 4 \\
\text { ( } \mathrm{I} \text { is central strain) }\end{array}$ & Group 5 & 97 & 85 & $5 \cdot 7$ & 74 & $8 I$ & 74 & $4 \cdot 6$ & 66 \\
\hline $\begin{array}{l}\text { Group } 5 \\
(2 P \text { is central strain) }\end{array}$ & Group 6 & 89 & 84 & $4 \cdot 9$ & 75 & $6 r$ & 50 & 6.8 & 38 \\
\hline $\begin{array}{l}\text { Group } 6 \\
\text { (b7F is central strain) }\end{array}$ & Group 7 & 91 & 86 & $4 \cdot 3$ & 77 & 53 & 46 & $*$ & 40 \\
\hline $\begin{array}{l}* \text { Not } \\
1=1 \\
2=1 \\
3=C \\
4=I\end{array}$ & $\begin{array}{l}\text { pplicable. } \\
\text { hest S valu } \\
\text { an S value } \\
\text { e standard } \\
\text { vest S valu }\end{array}$ & $\begin{array}{l}\text { in } \\
\text { th } \\
\text { via }\end{array}$ & t. & & & & & & \\
\hline
\end{tabular}

If the groups are drawn out spatially they form a network, not the succession of different types as the linear order of the rearranged $S$ value matrix might suggest. An attempt to represent this in a two-dimensional plan is given in Fig. 2. This construction is based on the central strain of each group, i.e. the organism possessing the least standard deviation in its $S$ values to the remainder of the strains of the group. These have been arranged relative to each other by way of 'best fits' using $\log _{2}$ I/S (Rogers \& Tanimoto, 1960) as the measure of distance. As the production of these diagrams involves the condensation of large amounts of data into two dimensions, it is considered that the method used here is sufficient to achieve a simple over-all picture of interrelationships. A more precise method for calculating the relative positions of the groups has been suggested by Rayner (1965).

The heterogeneity of the groups themselves is represented by the circle of radius 
$2 \sqrt{ }\left(\Sigma d^{2} / n\right)$ (Gyllenberg, 1965), where $d$ is the distance of the strains from the central strain of the group and $n$ the number of strains within the group. Any overlap of these circles does not necessarily indicate that the two groups concerned merge into each other, the circles only indicate the diversity of the individual groups: in most cases the groups concerned are possibly in different planes. When drawn out in the two dimensional state, planes may be drawn which serve to segregate the species according to certain characteristics which were highly correlated with other tests in the analyses, e.g. autotrophy/heterotrophy and final $\mathrm{pH}$ attained in culture; tests which would be termed 'key features' of conventional systematics.

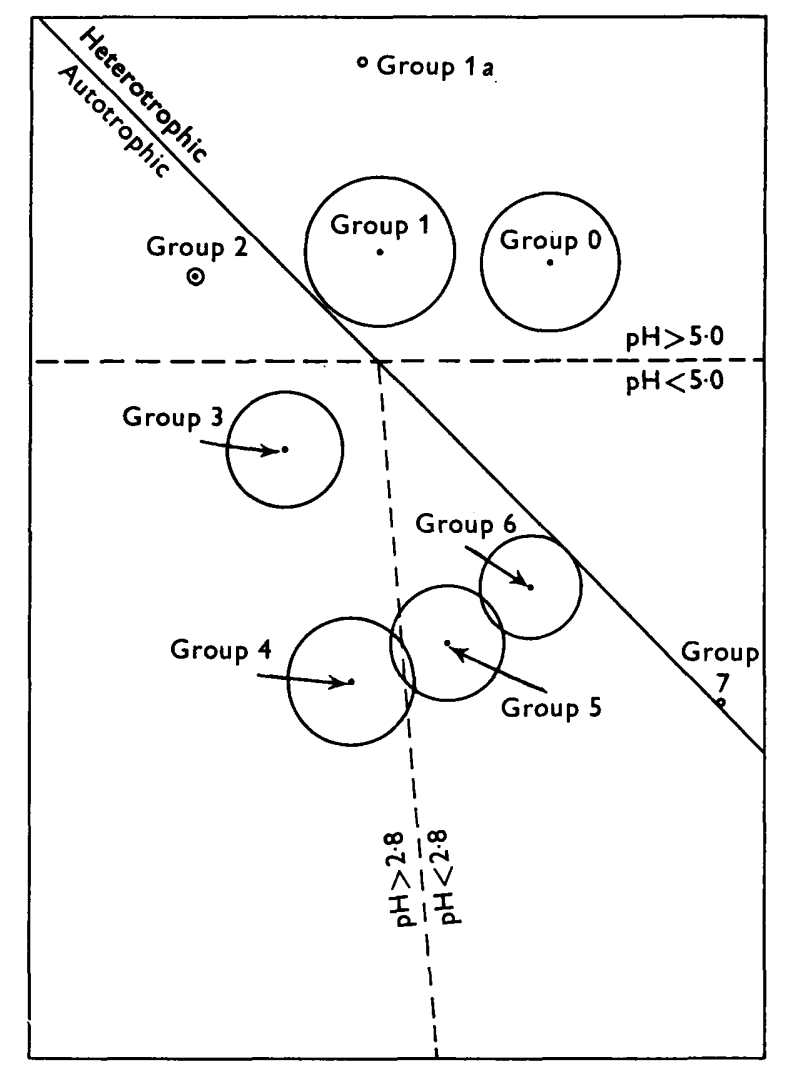

Fig. 2. Plan of the relationships of the groups of thiobacilli showing planes which separate the groups according to specific characters. Relative distance of the groups is based on the relationship $\log _{2} \mathrm{I} / \mathrm{S}$ for the centrotype of each group. The area of the circles is proportional to the range of $S$ values within the group according to the expression: radius $=2 \sqrt{ }\left(\Sigma d^{2} n\right)$, where $d$ is the distance in terms of difference in $\mathbf{S}$ value between each strain and the centrotype of the group and $\boldsymbol{n}$ is the number of strains within the group.

For the reasons given, it would be unwise to regard this total analysis as representing a true picture of the relationships of the various groups of thiobacilli. Therefore greater attention should be paid to the individual analyses where the strains have been compared directly with others under the same condition of growth. This is not so much a failing of Adansonian principles but is specific to the groups of organisms 
involved, for there can be few genera of bacteria in which the species cannot be tested under the same physiological conditions so that direct comparisons may be made between them.

The results of this work indicate that the classification of Parker \& Temple (I957) is basically correct, though certain of the diagnostic criteria have been found to be invalid. Our assessment of the status of the various species is given in Table 4 .

Table 4. List of species and redundant names of the thiobacilli

$\quad$ Species
Thiobacillus
novellus
$T$. denitrificans
$T$. thioparus
$T$. neapolitanus
$T$. thio-oxidans
$T$. ferro-oxidans
$T$. intermedius
Group I a
Ferrobacillus
ferro-oxidans
$F$. sulfo-oxidans
$T$. thiocyanoxidans
$T$. concretivorus
$T$. coproliticus
$T$. thermophilica
Strain I D
$T$. trautweinii

Original description

Comments

Starkey $(1934,1935 a, b)$

Good species

Beijerinck (1904a, b)

Starkey (I935 $a, b)$

Parker \& Prisk (1953)

Waksman \& Joffe (1921, 1922)

Temple \& Colmer (I95I)

London (1963)

Hutchinson et al. (this work)

Good species

Type species

Good species

Good species

Good species

Good species

Doubtful species

Leathen \& Braley (1954)

Kinsel (1960)

Happold et al. (1954)

Parker (1945)

Lipman \& McLees (1940)

Egorova \& Deryugina (1963)

Hutchinson \& White (1964)

Redundant, now name $T$. ferro-oxidans

Redundant, new name $T$. ferro-oxidans

Redundant, new name $T$. thioparus

Not examined in the present study

Not examined in the present study

Probably different genus

Probably different genus

Many heterotrophic strains are of this

type and should not be regarded as

thiobacilli

\section{Procedure for the identification of an unknown strain of Thiobacillus}

To achieve an unambiguous identification, the following procedure should be strictly adhered to, paying particular attention to the time factor.

The culture should first be inoculated into both $\mathrm{S}_{5}$ and S6 media to determine the appropriate $\mathrm{pH}$ value for the tests. Experience has shown that it is necessary to passage iron oxidizing strains suspected of being thiobacilli, through a sulphur medium before testing them in thiosulphate.

Test media should be inoculated with approximately $0.02 \mathrm{ml}$. of a 3-day-old culture under the following standard conditions which should be adhered to throughout the test series. These conditions consist of growing the strains at $28^{\circ}$ in $10 \mathrm{ml}$. quantities of the appropriate medium contained in $50 \mathrm{ml}$. conical flasks in static culture to ensure an adequate but uniform, degree of aeration. Growth is determined by the amount of thiosulphate oxidized and the $\mathrm{pH}$ value after 28 days.

The deposition of sulphur intercolonially is determined by microscopical examination of the culture on thiosulphate agar over a period of up to 28 days. Sulphur appears, by transmitted light, as a black opaque material which may be of a crystalline or globular form. Both of these forms have proved to be sulphur by X-ray analysis. Certain strains of group 0 produce a white intercolonial deposit which appears as a 'brown' amorphous deposit on microscopical examination by transmitted light. This material has been identified as sodium sulphate by X-ray analysis. 


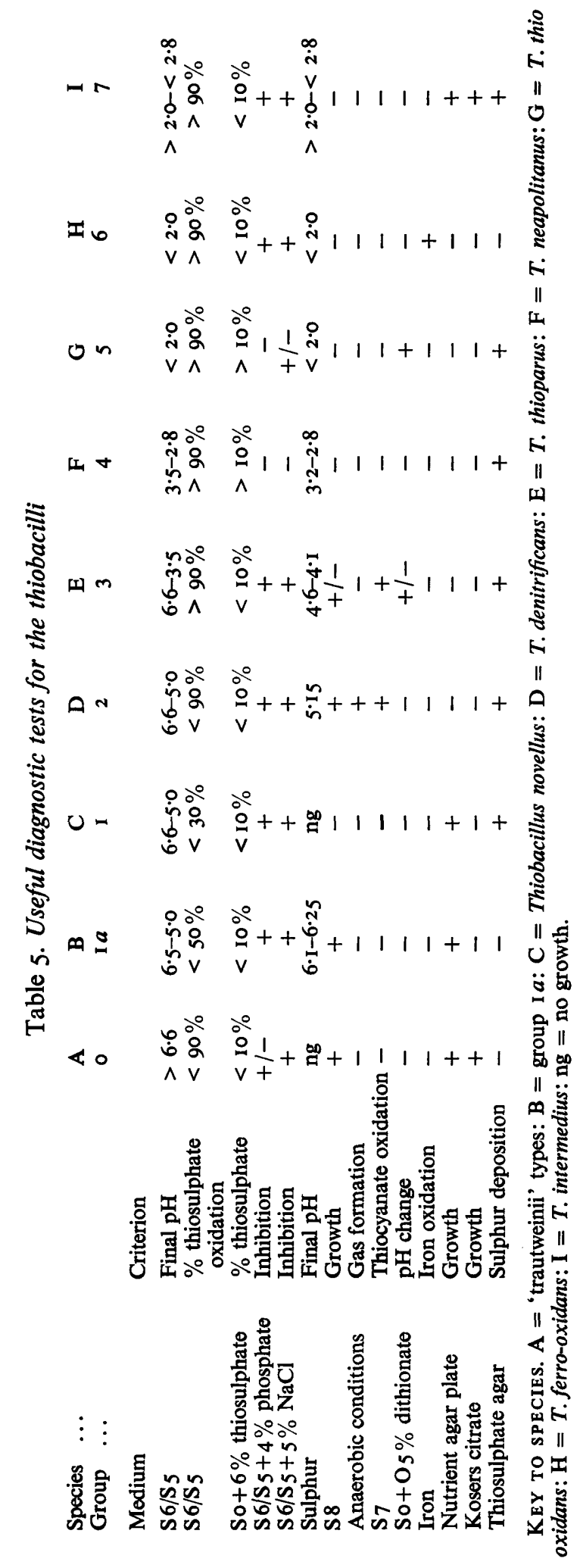




\section{The identification and description of the species of the genus Thiobacillus}

In view of the extended period for which the diagnostic tests must be run, the normal dichotomous key has been discarded in favour of the diagnostic table suggested by Cowan \& Steel (I96I). The relevant test media and diagnostic criteria are listed in Table 5.

The most important of these criteria is the final $\mathrm{pH}$ attained in the $\mathrm{S} 6$ or $\mathrm{S} 5$ medium and the majority of the other tests should be regarded as confirmatory. Data on the individual species which are not easily tabulated are included in the following brief descriptions.

Table 6. The effect of the initial $p H$ of the medium and its effect on the utilization of thiosulphate by certain facultative autotrophic strains

\begin{tabular}{|c|c|c|c|c|c|c|}
\hline Group... & & & & & & \\
\hline Strain... & & & & & & \\
\hline $\begin{array}{l}\text { Initial pH of } \\
\text { thiosulphate } \\
\text { modium }\end{array}$ & $\begin{array}{c}\text { Thio- } \\
\text { sulphate } \\
\text { used } \\
(\%)\end{array}$ & $\begin{array}{c}\text { Final } \\
\text { pH }\end{array}$ & $\begin{array}{l}\text { Thio- } \\
\text { sulphate } \\
\text { used } \\
(\%)\end{array}$ & $\begin{array}{c}\text { Final } \\
\text { pH }\end{array}$ & $\begin{array}{l}\text { Thio- } \\
\text { sulphate } \\
\text { used } \\
(\%)\end{array}$ & $\begin{array}{c}\text { Final } \\
\text { pH }\end{array}$ \\
\hline 5.05 & 0 & 5.05 & 0 & 5.05 & 0 & $5 \cdot 05$ \\
\hline $6 \cdot 5$ & 42 & $7 \cdot 65$ & 44 & $7 \cdot 7$ & 10 & 5.5 \\
\hline $7 \cdot 6$ & 17 & $8 \cdot 2$ & 20 & $8 \cdot 55$ & 19 & $5 \cdot 15$ \\
\hline
\end{tabular}

Results were read after 28 days incubation at $28^{\circ}$.

Group o (' $T$. trautweinii'). The members of this group are facultatively autotrophic and oxidize thiosulphate to tetrathionate with a corresponding increase of the $\mathrm{pH}$ value. As reported previously (Hutchinson et al. 1965), this group is very heterogenous and subsequent electron micrographs have shown that one of the two authentic strains of ' $T$. trautweinii' is peritrichously flagellated whereas the genus Thiobacillus is defined as consisting of Gram-negative, rod-shaped cells; non-motile or motile, by means of a single polar flagellum (Parker \& Temple, 1957). For these reasons it is proposed to exclude these organisms from the genus Thiobacillus even though certain of them may oxidize greater amounts of thiosulphate than other undoubted thiobacilli, as shown in Table 6. They have been included in this study for completeness because representatives of this group are commonly encountered in nature (Trudinger, 1967).

Group $x$ ( $T$. novellus). These organisms are facultative autotrophs which oxidize thiosulphate with the production of a small amount of acid; the reaction of S6 medium may fall below that of the control but never below $\mathrm{pH} 5^{\circ} 0$. Thiosulphate utilization is small (usually less than $20 \%$ ) though this is probably a reflexion of the limited acid tolerance of these strains (Table 6). The addition of greater amounts of buffer does not significantly increase the amount of thiosulphate used, because these strains are very sensitive to increased salt concentrations. They do not tolerate the inhibitory compounds used in the test scheme.

Heterotrophically, these organisms are very limited in their reactions; they are oxidase-positive, catalase-negative, unable to utilize citrate as sole source of carbon, do not reduce nitrate, do not hydrolyse arginine, tributyrin, tallow or starch, acid is not formed in glucose or lactose, acetylmethylcarbinol and indole are not produced, 
gelatin is not liquefied and there is no change in litmus milk. Contrary to the findings of Starkey (1935a), growth on a potato plug has not been observed and no pigments were formed on any media. The only readily discernable heterotrophic property for these strains is their growth in proteinaceous media, which is characterized by the formation of streamer like growths extending from the surface of the medium to the bottom of the vessel. This form of growth was described by Starkey (1935b).

The original strain isolated by Starkey is widely available. An organism (I L) was isolated in the course of the present study which resembled the authentic strains.

Group I $a$. Although only two isolates of this group have been examined, the characters studied would suggest that they represent a valid group in that they are facultatively autotrophic and produce a slight acidity (pH 6.0) in S6 medium. Moreover, the amount of thiosulphate oxidized is greater than that of $T$. novellus under standard conditions. These strains differ from $T$. novellus in their ability to grow anaerobically in thiosulphate media, but fail to produce visible evidence of denitrification. In nitrate peptone broth, however, nitrogen gas is formed. Citrate is utilized as the sole source of carbon. The numerical analysis has shown that these strains may represent a new species, but it is thought that more strains should be examined before a name is given. Similar strains were described by Tjulpanova-Mossevitch (1930) and Sijderius (1946).

Group 2 (T. denitrificans). These are autotrophic strains which are able to oxidize sulphur, thiosulphate and thiocyanate under anaerobic conditions in the presence of nitrate. This latter anion is reduced to nitrogen gas which is clearly visible when these organisms are grown in completely filled and stoppered bottles. Good growth is obtained on solid media containing thiosulphate and nitrate when incubated in a McIntosh \& Fildes jar and large amounts of elementary sulphur are deposited intercolonially.

Organisms of this group are also capable of aerobic growth but under these conditions the amount of thiosulphate used is considerably reduced. This is a reflexion on the unfavourable $\mathrm{pH}$ attained $\left(\mathrm{pH} 5^{\circ} 0\right.$ ). This does not occur under anaerobic conditions as the fall in $\mathrm{pH}$ is moderated by the products of the nitrate reduction. (Baalsrud \& Baalsrud, 1954). This species resembles $T$. thioparus in its sensitivity to inhibitory compounds.

Strains of this species appear to have been isolated at intervals since the original description by Beijerinck (1904a, $b$ ), but no authentic strains of $T$. denitrificans could be located. The strains of this group isolated during the course of this work have been deposited with the National Collection of Industrial Bacteria, accession numbers 9546, 9547 and 9548 .

Group 3 (T. thioparus). As with group 2, these organisms oxidize thiocyanate, thiosulphate and sulphur under aerobic conditions. The final $\mathrm{pH}$ value with the two latter substrates is always below 5.0 but never less than $\mathrm{pH} 3.5$. Although essentially aerobic, they possess a limited ability to grow anaerobically in that colonies are produced on thiosulphate-nitrate agar in a McIntosh \& Fildes jar; unlike $T$. denitrifcans, they die out with prolonged anaerobic cultivation. In liquid anaerobic culture, gas production has never been observed, nor appreciable amounts of thiosulphate or thiocyanate used. These strains are inhibited by many of the compounds listed in Table 2, and in some cases the final $\mathrm{pH}$ is greater than $7^{\circ} 0$, indicating that the oxidation of thiosulphate has not proceded beyond the tetrathionate stage. 
Thiobacillus thioparus is regarded as the type species of this genus. Many authentic strains of this species are available and it is readily isolated from a wide variety of sources. All the named strains of $T$. thiocyanoxidans examined were grouped with T. thioparus.

Group 4 (T. neapolitanus). This species differs from $T$. thioparus in that it is unable to oxidize thiocyanate, or grow anaerobically. Thiosulphate and sulphur are oxidized with the production of acid which becomes inhibitory when the $\mathrm{pH}$ falls to $2 \cdot 8$. In I \% thiosulphate liquid medium the amount of sulphur deposited varies from strain to strain. Strains of $\boldsymbol{T}$. neapolitanus are very resistant to inhibitors and in general are not affected by $6 \%$ thiosulphate, $4 \%$ phosphate, $5 \%$ sodium chloride, $\mathrm{I} \%$ sodium glutamate or 100 p.p.m. phenol.

They have been isolated from many sources, and some strains of this species have been incorrectly described as $T$. thioparus.

Group 5 (T. thio-oxidans). This species oxidizes sulphur, hydrogen sulphide and thiosulphate with the production of $\mathrm{pH}$ values below 2.0. As Kempner (1966) has shown, when grown in a medium containing sulphur $\mathrm{pH}$ values below $\mathrm{I} \cdot 0$ may be recorded and viable bacteria recovered. Initiation of growth in thiosulphate media only occurs in the $\mathrm{pH}$ range 4.0 to 5.7 but in sulphur-containing media this $\mathrm{pH}$ range extends from $3 \cdot 0$ to $6 \cdot 4$.

Thiobacillus thio-oxidans shares with group 4 a resistance to high salt concentrations which are inhibitory to most other species of thiobacilli. Tolerance to intense acidities is the only reliable character which serves to differentiate these two groups. On solid media this intense acid formation by $T$. thio-oxidans produces a characteristic fogging of the agar around the colonies.

Strains of this species are easily isolated from acidic environments, particularly those associated with mining operations. The only named culture of $T$. concretivorus which could be included in the analysis was classified in group 5 and no new isolate corresponding to this species was found.

Group 6 (T. ferro-oxidans). In sulphur- and thiosulphate-containing media this species resembles $T$. thio-oxidans with respect to final $\mathrm{pH}$ value but, unlike the latter species, ferrous iron may also be used as the sole energy source. It also differs in that hydrogen sulphide is not metabolized by $T$. ferro-oxidans and growth is inhibited by the high concentrations of salts and organic compounds used in this study.

A further diagnostic criterion is their colony form on thiosulphate agar on which characteristic colonies are produced with a flat profile, irregular shape and a crystalline intercolonial deposit. This material gives them the frosty appearance described by Colmer, Temple \& Hinkle (1950); Colmer (1962).

Strains of this species have been isolated from acid mine waters, a natural ferruginous water and domestic sewage. All the named strains of the iron-oxidizing species $T$. ferro-oxidans, Ferrobacillus ferro-oxidans and $F$. sulfo-oxidans, were placed in one group by the numerical analysis. Because all of these species oxidize sulphur, thiosulphate and ferrous iron, it is considered that certain of these names are redundant. A possible explanation of the reported differences in the substrate utilization by these species was reported previously (Hutchinson et al. 1966).

Group 7 ( $T$. intermedius). Only two strains of this group have been examined; the original isolate of London (1963) and a similar strain isolated during this study. They both possess the unusual combination of characters of facultative heterotrophy and 
acid tolerance. In sulphur or thiosulphate media they produce final $\mathrm{pH}$ values in the range $2 \cdot 0$ to $2 \cdot 8$.

In thiosulphate media these strains are inhibited by the various inorganic compounds used in the test scheme but, in general, the organic inhibitors have no effect.

Heterotrophically, these organisms grow to a limited extent in nutrient broth or nutrient agar and this is marginally improved by the addition of yeast extract. Citrate is utilized as the sole source of carbon.

Thiobacillus thermophilica (Egorova \& Deryugina, 1963) was also examined and it was confirmed that this organism is strictly a thermophilic autotroph, though its exceptional morphology in being a spore former probably singles it out as belonging to a different genus. Similarly, the evidence for strain ID, a heterotrophic isolate which possesses the ability to grow autotrophically on thiocyanate but not on thiosulphate, is against its inclusion in the genus Thiobacillus (Hutchinson \& White, 1964).

\section{DISCUSSION}

The apparent degree of success achieved by the application of numerical analysis in this genus may be attributed to the occurrence of species which form discrete groups with no intermediate forms. In certain other analyses the species, and even genera, were not discontinuous and in these cases numerical analysis was of limited applicability (Graham, 1964; Kreig \& Lockhart, 1966). Although numerical taxonomy gives rise to groupings it does not in any way identify them. This may be done by the inclusion of authentic cultures in the analysis or by the comparison of the original test results with descriptions from the literature. Both methods have been used to name the groups found in this analysis and in general, most of the groups correspond to the species recognized by Parker \& Temple (1957).

A recent adjunct to systematics utilizes DNA base composition in that related bacterial species should have a similar over-all base composition. This concept was applied by Jackson, Moriarty \& Nicholas (1968) to test the homogeneity of certain autotrophs, notably authentic cultures of thiobacilli. Their findings are almost in complete agreement with the present multivariate analysis. However, although it is possible for two species to have the same over-all base composition, the base sequences can be entirely different resulting in completely different phenotypic expression. This is well illustrated in the work of Jackson et al. (1968), who found G+C base compositions of $56 \%$ and $57 \%( \pm \mathrm{I} \%$ ) for Thiobacillus neapolitanus and $T$. ferro-oxidans which are very different physiologically and biochemically. It is considered that DNA base ratios may not in themselves be diagnostic at the species level.

For the purpose of numerical analysis, several new differential tests have been investigated and certain of these have proved to be diagnostic. The diagnostic tests are listed in Table 5. Of all the tests, the most conclusive are those which depend upon the utilization of an unusual substrate such as thiocyanate or ferrous iron. The differentiation based on final $\mathrm{pH}$ attained is also important, provided a strict experimental procedure is adopted which allows growth to proceed to completion without any physical or chemical constraints being applied. Inhibitory conditions tend to produce an incomplete metabolism of thiosulphate to tetrathionate with a corresponding rise in $\mathrm{pH},{ }_{4} \mathrm{Na}_{2} \mathrm{~S}_{2} \mathrm{O}_{3}+2 \mathrm{H}_{2} \mathrm{O}+\mathrm{O}_{2}=2 \mathrm{Na}_{2} \mathrm{~S}_{4} \mathrm{O}_{6}+4 \mathrm{NaOH}$. Vishniac \& Trudinger (I962) have described a similar phenomenon with respect to the availability of oxygen. 
Several of the diagnostic tests which have been suggested previously for this genus were found to be unsatisfactory. All the strains examined produced polythionates under our test conditions with the possible exception of Thiobacillus novellus. With this organism the amount of thiosulphate metabolized was so small that the detection of polythionates was outside the experimental error of the analytical method. Although these results differ from those of Parker \& Temple (1957) similar findings have been reported by Pankhurst (1964).

It has been suggested (Parker \& Prisk, 1953) that the form of the nitrogen source might be used as a diagnostic test, but our experiments suggest that it is difficult to obtain an absence of growth in nitrogen free media used for control purposes despite all reasonable precautions to exclude possible sources of nitrogen contamination.

Baalsrud (I954) suggested that the thiobacilli may represent a spectrum of types in that he could arrange all of his isolates in a series according to the final $\mathrm{pH}$ attained in culture. In this study considerable attention has been given both to the $\mathrm{pH}$ value at which growth may be initiated and also the final value after 28 days. The latter closely paralleled the findings of Baalsrud (1954). Our work would indicate, however, that the spectrum is not continuous as there has been no evidence of interchange of strains of one group with another and the lower limits of the final $\mathrm{pH}$ values are extremely stable. This property has proved the most fundamental and reliable diagnostic feature of these organisms and is in every case correlated with other characteristics.

Bunker (1936) was of the opinion that a spectrum of types merging from the autotrophic thiobacilli to common heterotrophs may be possible. The number of thiobacilli which possess heterotrophic abilities is increasing with the discovery of new species such as $T$. intermedius, and possibly the group I $a$ and strain I $\mathrm{D}$ in the present study. This is further supported by reports in the literature of an iron-oxidizing strain which has been reported to grow on glucose (Remsen \& Lundgren, 1963) and similarly for a strain of $T$. thio-oxidans (Borichewski \& Umbreit, 1964, 1966). This suggests that there may be a series of these organisms, each of which could conceivably represent a heterotrophic analogue of the unknown obligate autotrophs.

No difficulty was experienced in isolating a sufficient number of strains of most species with the exception of $T$. novellus, $T$. intermedius and the new group $\mathrm{I} a$. This may have occurred because they may be comparatively rare in nature, or alternatively special techniques are required for their isolation. Such species, however, do give rise to difficulties in numerical analysis because the possible extent of the group cannot be judged from only one or two strains. These considerations suggest that the absence of intermediate forms between the groups in this study may simply be a function of the number of isolates examined, and increasing this by a suitable factor may have led to the recognition of intermediate forms.

As interspecies change had been encountered previously in this genus (Johnstone, Townshend \& White, 196r) all the stock cultures were carefully observed at frequent intervals for a repetition of this phenomenon. However, there were only four instances in which unusual strains were found associated with the stock cultures which, in view of the maintenance of over roo cultures for a period of three years, could possibly represent contamination. No unusual strains were encountered when a number of representative isolates were regularly subcultured either on solid media, liquid then solid media, or solely in liquid over a period of six months. 
The authors wish to thank Professor A. L. Roberts for his continued support of this programme and the British Coke Research Association for financial assistance. We are grateful to the many research workers who supplied the cultures used in this project.

\section{REFERENCES}

BaAlsRud, K. (1954). Physiology of thiobacilli. Symp. Soc. gen. Microbiol. 4, 54.

BaAlsrud, K. \& BaAlsRUd, K. S. (1954). Studies on T. denitrificans. Arch. Mikrobiol. 20, 34.

BEERS, R. J. \& LOCKHART, W. R. (I962). Experimental methods in computer taxonomy. J. gen. Microbiol. 28, 633.

BeiJerinck, M. W. (1904a). Phénomenès de réduction produits par les microbes. Archs néerl. Sci., Ser. 2, 9, I3I.

BeIJERINCK, M. S. (1904b). Uber die Bakterien, welche sich im Dunkeln mit Kohlensaure als Kohlenstoffquelle ernähren konnen. Zentbl. Bakt. (2. Abt) II, 593.

BJRICHEWSKI, R. M. \& UMBREIT, W. W. (1964). Growth of a Thiobacillus thio-oxidans on glucose. Bact. Proc. p. 92.

BORICHEWSKI, R. M. \& UMBREIT, W. W. (1966). Growth of Thiobacillus thio-oxidans on glucose. Archs Biochem. Biophys. 116, 97.

BUNKER, H. J. (1936). A review of the physiology and biochemistry of the sulphur bacteria. Spec. Rep. Chem. Res. Bd D.S.I.R. no. 3.

Colmer, A. R., Temple, K. L. \& Hinkie, M. E. (1950). An iron oxidizing bacterium from the acid drainage of some bituminous coal mines. J. Bact. 59, 317.

Colmer, A. R. (1962). Relation of the iron oxidiser, $T$. ferro-oxidans, to thiosulphate. J. Bact. 83, 76r.

Cowan, S. T. \& SteEL, K. J. (196I). Diagnostic tables for the common medical bacteria. J. Hyg., Camb. 59, 357.

Egorova, A. A. \& Deryugina, Z.P. (1963). The spore forming thermophilic Thiobacterium, T. thermophilica (Imschenetskii). Mikrobiologiya 32, 439.

Graham, P. H. (1964). The application of computer techniques to the taxonomy of the root nodule bacteria of legumes. J. gen. Microbiol. 35, 51 I.

GYLLENBERG H. G. (1965). A model for computer identification of micro-organisms. J. gen. Microbiol. 39, 40I.

HAPPOLD, F. C., JohnStone, K. I., Rogers, H. J. \& YouatT, J. B. (1954). The isolation and characteristics of an organism oxidizing thiocyanate. J. gen. Microbiol. Io, 26I.

Hutchinson, M. \& WhITE, D. (1964). The types and distribution of thiobacilli in biological systems treating carbonization effluents. J. appl. Bact. 27, 244.

Hutchinson, M., JohNSTONE, K. I. \& WHITE, D. (1965). The taxonomy of certain Thiobacilli. J. gen. Microbiol. 4I, 357.

Hutchinson, M., Johnstone, K. I. \& WhITE, D. (1966). Taxonomy of the acidophilic thiobacilli. J. gen. Microbiol. 44, 373.

HUTCHINSON, M., JoHNSTONE, K. I. \& WHITE, D. (1967). Taxonomy of anaerobic thiobacilli. J. gen. Microbiol. 47, 17.

JohNSTONE, K. I., TOWNSHEND, M. \& WHITE, D. (1961). Interspecies change in thiobacilli. J. gen. Microbiol. 24, 201.

JACKSON, J. F., MORIARTY, D. J. W. \& Nicholas, D. J. D. (1968). Deoxyribonucleic acid base composition and taxonomy of thiobacilli and some nitrifying bacteria. J. gen. Microbiol. 53, 53.

KeMPNER, E. S. (1966). Acid production by Thiobacillus thio-oxidans. J. Bact. 92, 1842.

KINSEL, N. A. (1960). A new sulphur oxidising bacterium: Ferrobacillus sulfo-oxidans. J. Bact. 80, 628.

KREIG, R. E. \& LOCKHART, W. R. (1966). Classification of Enterobacteria based on overall similarity. J. Bact. 92, 1275.

Leathen, W. W. \& BRAley, S. A. (1954). A new iron oxidising bacterium Ferrobacillus ferro-oxidans. Bact. Proc. p. 44.

LipMAN, C. B. \& MCLeEs, E. (1940). A new species of sulphur oxidising bacteria from coprolite. Soil Sci. 50, 429. 
London, J. (1963). Thiobacillus intermedius nov.sp.: A novel type of facultative autotroph. Arch. Mikrobiol. 46, 329.

Pankhurst, E. S. (1964). Polarographic evidence of the production of polythionates during the bacterial oxidation of thiosulphate. J. gen. Microbiol. 34, 427.

PARKER, C. D. (1945). The isolation of a species of bacteria associated with the corrosion of concrete exposed to atmosphere containing $\mathrm{H}_{2} \mathrm{~S}$. Aust. J. exp. Biol. med. Sci. 23, $8 \mathrm{I}$.

Parker, C. D. \& Prisk, J. (1953). The oxidation of various inorganic compounds of sulphur by various sulphur bacteria. J. gen. Microbiol. 8, 344.

PARKer, C. D. \& Temple, K. L. (1957). In Bergeys Manual of Determinative Bacteriology, 7 th ed., p. 83. London: Baillière, Tindall and Cox, Ltd.

RAYNER, J. H. (1965). Multivariate analysis of montmorillonites. Clay Minerals, 6, 59.

Remsen, C. C. \& Lundaren, D. G. (I963). Heterotrophic growth of the chemo-autotroph Ferrobacillus ferro-oxidans. Bact. Proc. p. 33.

Rogers, D. J. \& TANIMOTO, T. T. (I960). A computer program for classifying plants. Science, N.Y. I32, III 5 .

SIJDERIUS, R. (1946). Heterotrophe bakterien die thiosulfaat oxydeeren. Thesis, University of Amsterdam, Netherlands.

SNEATH, P. H. A. (1957). The application of computers to taxonomy. J. gen. Microbiol. 17, 201.

StARKEY, R. L. (1934). Cultivation of organisms concerned in the oxidation of thiosulphate. J. Bact. 28, 365 .

StARKey, R. L. (1935a). Products of the oxidation of thiosulphate by bacteria in mineral media. J. gen. Physiol. 18, 325.

STARKEY, R. L. (1935b). Isolation of some bacteria which oxidise thiosulphate. Soil. Sci. 39, 197.

Temple, K. L. \& Colmer, A. R. (1951). The autotrophic oxidation of iron by a new bacterium: Thiobacillus ferro-oxidans. J. Bact. 62, 605.

Trautwern, K. (192I). Beitrag zur Physiologie und Morphologie der Thionsaurebakterien (Omelianski). Zentbl. Bakt. II, 6r, I.

TRUDINGER, P. A. (1967). Metabolism of thiosulphate and tetrathionate by heterotrophic bacteria from soil. J. Bact. 93, 550.

TJulPanova-MosseVtTCh, M. V. (1930). Arch. d. Sci. Biol. U.S.S.R. 30, 203. Quoted in Bergey's Manual of Determinative Bacteriology, (1957) 7th ed., p. 86. London: Baillière, Tindall and Cox Ltd.

Vishniac, W. \& Trudinger, P. A. (I962). Carbon dioxide fixation and substrate oxidation in the chemosynthetic sulphur and hydrogen bacteria. Bact. Rev. 26, I68.

WaKSman, S. A. \& JofFE, J. (1921). Acid production by a new sulphur oxidising bacterium. Science, N.Y. 53, 216.

Waksman, S. A. \& JoFre, J. (1922). Thiobacillus thio-oxidans: A new sulphur-oxidising organism isolated from soil. J. Bact. 7, 239. 